\title{
EFFECT OF PRETREATMENTS ON QUALITY OF MINIMALLY PROCESSED COOKING BANANA VARIETY ALUKESEL (Musa acuminata $\times$ Musa balbisiana, ABB GROUP)
}

\author{
H. Siriwardana ${ }^{1}$ K. Abeywickrama ${ }^{1}$ and S. Kannangara ${ }^{1}$
}

ABSTRACT

Cooking banana is a vegetable which can be stored for longer periods in intact form but undergoes browning soon after slicing. A study was undertaken to evaluate the effect of selected pretreatments in maintaining quality of minimally processed cooking banana variety Alukesel. Minimally processed Alukesel was subjected to pretreatments of ascorbic acid (3\%), citric acid (3\%), ascorbic acid (2\%), citric acid (2\%), citric acid + ascorbic acid (1.5\% each), sodium metabisulphite (2\%) and distilled water (control), packed in polystyrene packages and stored at $5-7^{\circ} \mathrm{C}$ for a week. The effects of pretreatments on sensory and physicochemical properties (percentage weight loss, changes in firmness, pH, Total Soluble Solids (TSS) and Titratable Acidity (TA)) were evaluated on day 0 and day 7, while browning was assessed using a spectrophotometric method. Pretreatments had a significant effect on physicochemical and sensory attributes of minimally processed cooking banana compared to control. Ascorbic acid (3\%), citric acid (3\%) and citric acid + ascorbic acid (1.5\% each) pretreated cooking banana obtained higher ranking values for sensory properties (appearance, colour, odour, flavour, taste and overall acceptability) while the same three pretreatments and sodium metabisulphite (2\%) pretreatment effectively controlled enzymatic browning. This research revealed that pretreatments of ascorbic acid (3\%), citric acid (3\%) and citric acid + ascorbic acid (1.5\% each) were more successful in retaining quality of minimally processed cooking banana for one week in cold storage. It could be concluded that Alukesel treated as above can be considered as a potential value added sale item at local supermarkets where cold storage facility is available.

Keywords: Minimal processing, Cooking banana, physicochemical properties, sensory properties, browning

\section{INTRODUCTION}

Minimally processed products are fruits or vegetables that are trimmed, peeled, cut and packaged to offer consumers high nutrition, convenience and flavour while still maintaining freshness (Ahvenainen, 1996). Although food processing techniques stabilize the products and lengthen their storage and shelf life, minimal processing of fruits and vegetables increase their perishability. Therefore, conditions for processing of raw materials such as peeling, slicing, pre-treatments, packing and storing have to be carefully worked out to have a considerable shelf-life and quality acceptable to the consumer (Dharmabandu et al., 2007).
Physical, chemical and biochemical changes in minimally processed products occur at faster rates than in intact raw commodities due to tissue damages (Botelho et al., 2008). Live tissues in fresh cut products undergo enzymatic browning, softening and undesirable volatile production which could shorten the shelf-life than the whole produce. Oxidation of phenolic substrates by polyphenol oxidase (PPO) is believed to be the major cause of browning of many fruits and vegetables (Soliva-Fortuny and MartinBelloso, 2003). The enzymatic browning of fruits and vegetables has a negative visual impact, decreases the commercial quality, the 
sensory acceptance and the nutritional value of minimally processed foods (Artes et al., 1998).

To overcome these undesirable changes, cut produce are immersed in pre-treatment solutions at the final stage of handling operations. Compounds such as ascorbic and citric acids and sodium metabisulphite have been utilized in many parts of the world as suitable preservatives for maintaining quality of minimally processed produce such as potato and apple (Ahvenainen, 1996; Cortez-Vega et al., 2008).

Cooking banana variety Alukesel belonging to genus Musa (family Musaceae) is a hybrid derived from the species Musa acuminata and M. balbisiana. This commodity contains a high energy value including fiber, carbohydrate, vitamins and also high potassium content (Simmonds, 1966). Cooking banana consumed cooked, boiled, fried, roasted, or even brewed are a major staple food throughout the tropics while in Sri Lanka variety Alukesel is mainly used in curries.

This commodity could be stored for longer periods intact, however, undergoes browning soon after slicing. If this banana variety could be developed as ready to cook fresh cuts, they could be sold at local supermarkets as value-added product such as slices and chips. Currently, no published information is available on minimal processing of cooking banana variety Alukesel.

A preliminary research trial was conducted at University of Kelaniya, using ascorbic acid $(2 \%, 3 \%)$, citric acid $(2 \%, 3 \%)$, citric acid + ascorbic acid (1.5\% each), sodium metabisulphite $(2 \%)$, calcium chloride $(2 \%)$, sodium chloride $(2 \%)$, turmeric $(1 \%)$ and vinegar $(1 \%)$ as pretreatments during minimally processing of cooking banana variety Alukesel. Vinegar, turmeric, sodium chloride and calcium chloride were unable to control browning in banana slices (unpublished data). Based on the preliminary research trial, pretreatments which provided acceptable physicochemical, sensory and browning data were further tested for their importance in quality retention.

The objectives of the current research activity were to evaluate the effect of selected pretreatments (citric acid, ascorbic acid, sodium metabisulphite) in controlling browning of minimally processed cooking banana and to evaluate physicochemical and sensory properties in pretreated product packed in polystyrene packages and stored at $5-7{ }^{\circ} \mathrm{C}$ for 7 days. This research was carried out with the final objective of selecting the most appropriate pretreatments in maintaining quality of minimally processed cooking banana (Alukesel) under cold storage with the aim of identifying a value-added product to be introduced to the local supermarkets.

\section{MATERIALS AND METHODS}

\section{Preparation of cooking banana}

Cooking banana variety Alukesel (Musa acuminata $\times$ Musa balbisiana, ABB Group) of 90 day maturity was purchased from supermarkets in Kiribathgoda, Sri Lanka and transported to the laboratory at the Department of Botany, University of Kelaniya. Samples were peeled off and washed with distilled water and dipped in chilled water for 2 minutes. Subsequently, produce were cut into slices (8$10 \mathrm{~g}$ ) using a sharp stainless steel knife under aseptic conditions. The resulting slices were separately dipped in selected pretreatment solutions, singly or in combination such as ascorbic acid $(3 \% \mathrm{w} / \mathrm{v})$, citric acid $(3 \% \mathrm{w} / \mathrm{v})$, ascorbic acid $(2 \% \mathrm{w} / \mathrm{v})$, citric acid $(2 \% \mathrm{w} / \mathrm{v})$, citric acid + ascorbic acid (1.5\% w/v each), sodium metabisulphite $(2 \% \mathrm{w} / \mathrm{v})$ and distilled water (control) for 5 minutes. Samples were drained and air dried for 15 minutes and 8-10 slices were packed in polystyrene packages of $100 \mathrm{~g}$ capacity and sealed by placing clipon lids (Latifah et al., 2000). Packages were 
labeled and placed on plastic trays $(30 \mathrm{~cm} \times$ $40 \mathrm{~cm}$ ) and stored in a cold room at $5-7{ }^{\circ} \mathrm{C}$ and $80-85 \%$ relative humidity. Four replicate packages were used per treatment.

\section{Physicochemical analysis}

Samples were subjected to physicochemical analysis on day 0 and on day 7 .

Percentage weight loss: Weights of packages with cooking banana slices were recorded before and after storage in a cold room, using an electronic balance (Sartorius BP 6100, R \& $\mathrm{M}$ marketing, UK). The difference in the weight was expressed as the percentage weight loss (Anthony et al., 2003). Four replicate samples were used per treatment.

Total soluble solids (TSS): Ten (10) g sample of banana was blended with distilled water $(40$ $\mathrm{ml}$ ) in a homogenizer (Black \& Decker, BX 250, Hunt Valley, USA) for $2 \mathrm{~min}$. The homogenate was filtered through a muslin cloth and few drops of the filtrate was used to measure TSS using a hand-held Refractometer (ATC-1E, ATAGO Co. Ltd., Japan). Each reading was multiplied by the dilution factor to calculate the actual TSS content (Abeywickrama et al., 2004). Four replicate samples were used per treatment.

pH: $\mathrm{pH}$ of the filtrates were measured using a digital $\mathrm{pH}$ meter (PC 510, EUTECH Instruments, Singapore) (Anthony et al., 2003). Four replicate samples were used per treatment.

Titratable acidity (TA) (\% acid): Ten (10) $\mathrm{ml}$ samples of filtrates prepared for the TSS test were diluted with $20 \mathrm{ml}$ distilled water and titrated against $0.1 \mathrm{M} \mathrm{NaOH}$ with phenolphthalein as the $\mathrm{pH}$ indicator. The end point was taken as the sudden appearance of slight pink color in the solution. TA was calculated by multiplying the $\mathrm{NaOH}$ volume with the dilution factor and the malic acid factor (malic acid factor $=0.0067 \mathrm{~g}$ ). TA was expressed as \% malic acid (Abeywickrama et al., 2004). Four replicate samples were used per treatment.

Firmness: Firmness of cooking banana samples were measured using a Fruit Firmness Tester (FT 011, QA Supplies, Italy) using the protocol described by Anthony et al., (2003). Four replicate samples were used per treatment.

\section{Sensory properties}

Samples were subjected to sensory evaluation on day 0 and day 7. One hundred (100) g of sample subjected to pretreatments (or control) were boiled in a beaker with $500 \mathrm{ml}$ distilled water, by placing on a hot plate (AREX Heating magnetic stirrer, VELP Scientifica, Europe). This was considered as the cooked sample. One hundred (100) g of pretreated and control banana samples were fried in a pan with $500 \mathrm{ml}$ coconut oil, by placing on a hot plate as above. This was considered as fried samples. Cooked, fried and uncooked banana samples were provided to an untrained, 10 member taste panel along with a questionnaire developed in the laboratory on day 0 and day 7. Sensory evaluation for appearance, colour, odour, flavour, taste and overall acceptability was carried out using a 7 point ranking system (Dharmabandu et al., 2007). Appearance, colour and odour were evaluated from the uncooked samples while flavour and taste were evaluated using cooked and fried samples. Overall acceptability was evaluated considering the uncooked, cooked and fried samples. Twenty replicate samples were used per treatment.

\section{Degree of Browning}

Cooking banana slices were prepared as previously described and samples were dipped in different pretreatment solutions for 5,10 and 15 minutes separately. Treated samples were drained and air dried for 15 minutes. A $2.50 \mathrm{~g}$ portion from each treated sample was 
homogenized with $2.5 \mathrm{ml}$ distilled water and $7.5 \mathrm{ml}$ of $50 \%$ ethanol. The solution was well shaken and absorbance was measured at 420 $\mathrm{nm}$ keeping 50\% ethanol as the blank using a UV Spectrophotometer (GENESYS 10, USA) (Miller, 1998). Each determination was carried out in triplicate.

\section{Experimental design and statistical analysis}

The experimental units were arranged as a completely randomized design (CRD). Data obtained for sensory properties were subjected to Kruskal Wallis non-parametric test whereas, data obtained for physicochemical properties and degree of browning were subjected to General Linear Model using ANOVA, MINITAB statistical package. Treatment means were compared using the least significant difference at $\mathrm{p}=0.05$.

\section{RESULTS AND DISCUSSION}

\section{Physicochemical analysis}

Percentage weight loss: In our study, a weight loss between $0.00-0.54 \%$ was recorded for all treatments and the control after a storage period of 7 days, whereas the percentage weight loss was zero in 3\% citric acid treatment $\left(\mathrm{T}_{2}\right)$ and $2 \%$ sodium metabisulphite treatment $\left(\mathrm{T}_{6}\right)$ on day 7. A relatively higher weight loss $(0.54$ $\%$ ) was observed in the control $\left(\mathrm{T}_{7}\right)$. (Fig. 01.). Although pretreated cooking banana samples were packed in polystyrene packages, this low weight loss may occur due to the water loss through the relatively small pores present in the package.

Daranagama (2011), reported that minimally processed lotus root packed in polystyrene packages recorded a weight loss of 0.00 - $0.59 \%$ after 7 days of storage at 5-7 ${ }^{0} \mathrm{C}$ while minimally processed mixed amberella+pineapple showed a weight loss of $0.19-0.37 \%$ after 7 days of storage at $5-7$ ${ }^{0} \mathrm{C}$ (Daranagama et al., 2012). Furthermore, minimally processed onion which were packed in polypropylene containers and stored at $2{ }^{\circ} \mathrm{C}$, recorded a weight loss below $1 \%$ at the end of 30 days of storage (Zaulia et al., 2007). Low weight loss in commodity inside packages is a desirable character as it would maintain freshness of commodities during the shelf life at sale.

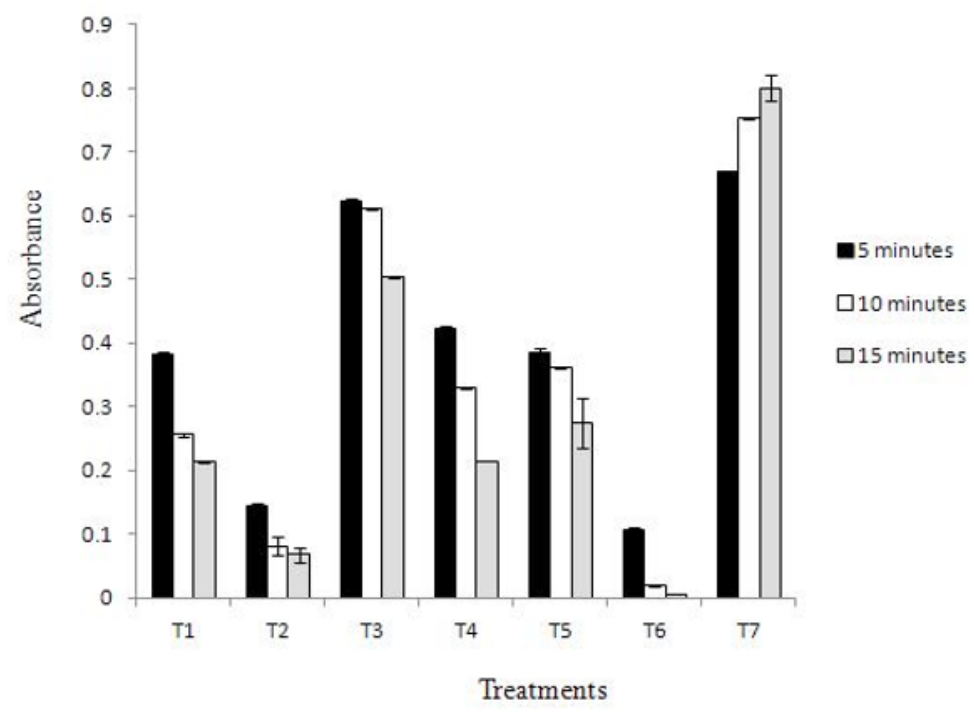

Figure 01. Effect of pretreatments on percentage weight loss of minimally processed cooking banana.

(T1 - 3\% (w/v) ascorbic acid, T2 - 3\% (w/v) citric acid T3 - 2\% (w/v) ascorbic acid, T4 - 2\% (w/v) citric acid, T5 - 1.5\% (w/v) citric acid $+1.5 \%(\mathrm{w} / \mathrm{v})$ ascorbic acid, $\mathrm{T} 6-2 \%(\mathrm{w} / \mathrm{v})$ sodium metabisulphite, $\mathrm{T} 7$ - distilled water (control)).

Each data point represents the mean of four replicates \pm standard error. 
Weight loss of a plant product is due to the transpiration and respiration of the product. Water loss reduces the postharvest life as it diminishes the turgidity associated with fresh appearance of fruits and vegetables. Furthermore, weight loss which is an economic loss is often related to reduction in fresh weight of the produce. It also leads into loss of value and undesirable quality (Latifah et al., 2008).

Total soluble solids (TSS): During the present research, TSS values remained more or less constant after subjecting to most of the pretreatments, while in certain others a slight variation with storage time was observed. The highest TSS value (3.50 ${ }^{\circ}$ Brix) was recorded in the $3 \%$ citric acid treated samples $\left(\mathrm{T}_{2}\right)$ (Table 01.). However, lower TSS values are to be expected in Alukesel variety as it is used for only cooking purposes and not as a dessert fruit.

During a similar study, when ambarella+pineapple was subjected to minimal processing and packed as a mixed load, highest TSS value was recorded for citric acid treated samples (Daranagama et al., 2012). According to Anthony (2003), untreated Embul banana packed in high density polyethylene recorded a TSS value of $4.2-4.5^{\circ}$ Brix after storage of 21 days at $13-14{ }^{\circ} \mathrm{C}$.

Dessert banana, cooking banana and plantain, contain many compounds which are soluble in water such as sugars, acids, vitamin C, amino acids and some pectins. These soluble compounds form the soluble solid content of the fruit. Increase in TSS content reflects hydrolysis of starch into sugars as banana fruits ripen, whereas decrease in TSS content is due to the utilization of carbohydrates as metabolites (Dadzie, 1998).

pH: A slight increment in $\mathrm{pH}$ could be observed on $7^{\text {th }}$ day of storage when compared to 0 day for all treatments except for $2 \%$ sodium metabisulphite $\left(\mathrm{T}_{6}\right)$ and control $\left(\mathrm{T}_{7}\right)$. However, the values varied within the range of $\mathrm{pH} 4.31$ - 5.45 in samples during the study period (Table 01.). Slightly low acidity in most of the samples except in control and metabisulphite, could be due to the treatment with individual or combinations of two organic acids.

The $\mathrm{pH}$ is dependent on the total quantity of acids as well as the strength of the acids present (Schmidl and Labuza, 2000). According to Daranagama et al., (2012) minimally processed amberella pretreated with ascorbic acid and citric acid stored at 5-7 ${ }^{\circ} \mathrm{C}$ showed slight increment of $\mathrm{pH}$ (lower acidity) after 7 days of storage. Mostofi et al., (2008) reported an increase in $\mathrm{pH}$ (lower acidity) with increasing storage period in untreated 'Shafi Abadi' Iranian apple which were packed in polyethylene and polypropylene containers stored at $4{ }^{\circ} \mathrm{C}$.

Titratable acidity (TA): A slight decrease in TA could be observed on $7^{\text {th }}$ day of storage when compared to 0 day for all treatments, except for $3 \%$ ascorbic acid $\left(\mathrm{T}_{1}\right)$ which recorded a slight increment. This may be due to the effect of the pretreatment itself. TA values of $2 \%$ ascorbic acid $\left(\mathrm{T}_{3}\right)$ and control $\left(\mathrm{T}_{7}\right)$ samples remained unchanged on 0 and 7 days. TA values were within the range of $0.18-0.74 \%$ on $7^{\text {th }}$ day (Table 01.). 


\section{Table 01. Effects of pretreatments on physicochemical properties of minimally processed cooking banana on day 0 and day 7.}

\begin{tabular}{|c|c|c|c|c|c|c|c|c|}
\hline \multicolumn{5}{|c|}{ Day 0} & \multicolumn{4}{|c|}{ Day 7} \\
\hline 选 & 吾 & מ & 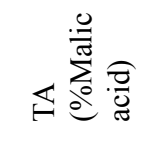 & 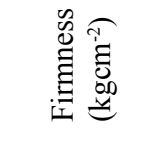 & 吾 & 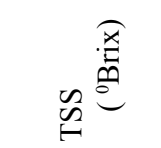 & 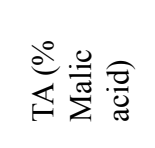 & 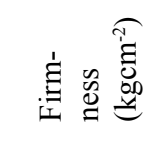 \\
\hline $\mathrm{T}_{1}$ & $4.68 \pm 0.00$ & $2.00 \pm 0.00$ & $0.43 \pm 0.00$ & $1.00 \pm 0.02$ & $4.96 \pm 0.00$ & $2.00 \pm 0.00$ & $0.50 \pm 0.00$ & $0.80 \pm 0.02$ \\
\hline $\mathrm{T}_{2}$ & $4.09 \pm 0.00$ & $3.00 \pm 0.00$ & $0.83 \pm 0.00$ & $1.22 \pm 0.01$ & $4.31 \pm 0.02$ & $3.50 \pm 0.28$ & $0.74 \pm 0.00$ & $1.11 \pm 0.01$ \\
\hline $\mathrm{T}_{3}$ & $4.88 \pm 0.02$ & $2.00 \pm 0.00$ & $0.23 \pm 0.00$ & $1.42 \pm 0.01$ & $4.31 \pm 0.02$ & $1.00 \pm 0.28$ & $0.23 \pm 0.00$ & $1.52 \pm 0.02$ \\
\hline $\mathrm{T}_{4}$ & $4.46 \pm 0.00$ & $2.00 \pm 0.00$ & $0.40 \pm 0.00$ & $1.51 \pm 0.01$ & $4.92 \pm 0.02$ & $2.00 \pm 0.02$ & $0.18 \pm 0.00$ & $1.42 \pm 0.03$ \\
\hline $\mathrm{T}_{5}$ & $4.46 \pm 0.02$ & $2.00 \pm 0.00$ & $0.56 \pm 0.00$ & $0.80 \pm 0.02$ & $4.66 \pm 0.00$ & $2.00 \pm 0.00$ & $0.50 \pm 0.00$ & $0.70 \pm 0.02$ \\
\hline $\mathrm{T}_{6}$ & $5.29 \pm 0.00$ & $3.00 \pm 0.00$ & $0.56 \pm 0.00$ & $1.16 \pm 0.02$ & $5.11 \pm 0.02$ & $3.25 \pm 0.25$ & $0.56 \pm 0.00$ & $0.88 \pm 0.04$ \\
\hline $\mathrm{T}_{7}$ & $5.55 \pm 0.00$ & $2.00 \pm 0.00$ & $0.33 \pm 0.00$ & $1.10 \pm 0.02$ & $5.36 \pm 0.01$ & $2.00 \pm 0.00$ & $0.33 \pm 0.00$ & $0.76 \pm 0.03$ \\
\hline
\end{tabular}

$\left(\mathrm{T}_{1}-3 \%(\mathrm{w} / \mathrm{v})\right.$ ascorbic acid, $\mathrm{T}_{2}-3 \%(\mathrm{w} / \mathrm{v})$ citric $\operatorname{acidT}-2 \%(\mathrm{w} / \mathrm{v})$ ascorbic acid, $\mathrm{T}_{4}-2 \%(\mathrm{w} / \mathrm{v})$ citric acid, $\mathrm{T}_{5}-1.5 \%(\mathrm{w} / \mathrm{v})$ citric acid $+1.5 \%(\mathrm{w} / \mathrm{v})$ ascorbic acid, $\mathrm{T}_{6}-2 \%(\mathrm{w} / \mathrm{v})$ sodium metabisulphite, $\mathrm{T}_{7}$ - distilled water (control)).

*Each data point represents the mean of four replicates \pm standard error. *P value for pretreatment: $\mathrm{pH}-0.00$; TSS-0.00; TA0.00; Firmness-0.00. *P value for time: $\mathrm{pH}-0.00$; TSS-0.51; TA-0.00; Firmness-0.00. ${ }^{*} \mathrm{P}$ value for interaction (pretreatment $\mathrm{x}$ time): $\mathrm{pH}-0.00$; TSS-0.00; TA-0.00; Firmness-0.00. $* \mathrm{P}<0.05$ indicates a significant difference among variable and control.

Titratable acidity is often expressed in terms of the predominant acid present (malic acid in banana). According to Daranagama et al., (2012) minimally processed amberella+pineapple pretreated with ascorbic acid and citric acid stored at $5-7^{\circ} \mathrm{C}$ showed a slight decrease of TA after 7 days of storage. As in the present study, TA values decreased with increasing storage period in untreated 'Shafi Abadi' apple which were maintained under modified atmospheres, packed in polyethylene and polypropylene containers (Mostofi et al., 2008). According to Anthony (2003), untreated Embul banana packed in high density polyethylene recorded a TA value of $0.20-0.22 \%$ after storage of 21 days at 13 $14{ }^{\circ} \mathrm{C}$.

Firmness: The Firmness of the samples from different treatments and control were within the range of $0.70-1.70 \mathrm{kgcm}^{-2}$ on day 7 . A slight decrease of firmness could be observed in almost all pretreated samples of cooking banana during this research with storage time including the control (Table 01.).

Firmness is an important attribute that determines the acceptance or rejection of minimally processed produce by consumers. According to Ekanayaka (2014), minimally processed immature jak fruit pretreated with citric acid and ascorbic acid showed a slight decrease in firmness after 7 days of storage at $5-7{ }^{\circ} \mathrm{C}$. According to Dadzie (1998), under storage at $27 \pm 1^{\circ} \mathrm{C}$, cooking banana showed a progressive loss of pulp firmness over the course of ripening. The pulp firmness decreased from an initial value of $1.20 \mathrm{~kg} \mathrm{~cm}^{-2}$ to $0.12 \mathrm{~kg} \mathrm{~cm}^{-2}$ from green mature stage to fully ripened stage. The decrease in firmness with storage may be due to the destruction of parenchymal cells, by the degradation of pectin with the loss of mechanical support from the cell wall leading to softening of the plant material.

\section{Sensory properties}

Least deterioration in colour of cooking banana was recorded in samples treated with $1.5 \%$ citric acid $+1.5 \%$ ascorbic acid $\left(\mathrm{T}_{5}\right)$ after a storage period of 7 days (Table 02.). In general, the samples treated with, $3 \%$ ascorbic acid $\left(\mathrm{T}_{1}\right), 3 \%$ citric acid $\left(\mathrm{T}_{2}\right)$ and $1.5 \%$ ascorbic acid $+1.5 \%$ citric acid $\left(\mathrm{T}_{5}\right)$ samples were ranked better than the others, where most 
of the members preferred them by providing a higher rank value for overall acceptability. The samples treated with $2 \%$ ascorbic acid $\left(\mathrm{T}_{3}\right), 2 \%$ citric acid $\left(\mathrm{T}_{4}\right)$ and control $\left(\mathrm{T}_{7}\right)$ were less preferred by the taste panelists on day 7 when rating appearance, colour and overall acceptability (score below 4) although they gained higher ranks for taste and flavour (Table 02.). $1.5 \%$ citric acid $+1.5 \%$ ascorbic acid treatment $\left(\mathrm{T}_{5}\right)$ was more effective than $2 \%$ citric acid $\left(\mathrm{T}_{4}\right)$ and $2 \%$ ascorbic acid treatment $\left(\mathrm{T}_{3}\right)$ indicating a better conservation of quality of minimally processed samples.

According to Daranagama (2011), minimally processed lotus root treated with $3 \%$ ascorbic acid, 3\% citric acid and a combination treatment of $3 \%$ ascorbic acid and $3 \%$ citric acid ranked better than the others for most of the sensory properties. Similarly, minimally processed pineapple+amberella treated with ascorbic acid and citric acids were of acceptable quality after seven days of storage at $5-7^{\circ} \mathrm{C}$ (Daranagama et al., 2012).

\section{Degree of Browning}

Most of the pretreatments tested for minimally processed cooking banana showed a reduction in absorbance during an indirect browning assay using spectrophotometric analysis with storage time except the control $\left(\mathrm{T}_{7}\right)$, which showed a gradual increment of browning with increasing time. Further, distilled water treatment (after 15 minutes) showed the highest absorbance value (0.800) and higher browning as no pretreatment was applied. According to the results, $2 \%$ sodium metabisulphite $\left(\mathrm{T}_{6}\right)$ treatment gave the lowest absorbance value (0.006) at $420 \mathrm{~nm}$ among all pretreated samples. Furthermore, 3\% citric acid $\left(\mathrm{T}_{2}\right), 3 \%$ ascorbic acid $\left(\mathrm{T}_{1}\right)$ and $1.5 \%$ citric acid $+1.5 \%$ ascorbic acid $\left(\mathrm{T}_{5}\right)$, showed lower absorbance values compared to the control, indicating less browning development in sample slices (Fig. 02.)

Enzymatic browning requires the presence of four different components; oxygen, oxidizing enzyme (polyphenol oxidase), metallic ion (copper) and a suitable substrate (phenolic substrate) (Ahvenainen, 1996). The polyphenol oxidases catalyse oxidation of phenolic compounds to produce quinones (1,4-Benzo, 1,4-Naphtho, and 9,10-Anthraquinone). Subsequently, quinones undergo further polymerization resulting in dark, insoluble polymers referred to as melanin (Marshall and Wei, 2000). Enzymatic browning can be inhibited by eliminating one or more of the essential factors required for the above reactions.

Table 02. Effects of pretreatments on sensory properties of minimally processed cooking banana on day 7 .

\begin{tabular}{ccccccccc}
\hline Treatment & Appearance & Colour & Odour & $\begin{array}{c}\text { Flavor/ } \\
\text { cooked } \\
\text { sample }\end{array}$ & $\begin{array}{c}\text { Flavor/ } \\
\text { fried } \\
\text { sample }\end{array}$ & $\begin{array}{c}\text { Taste/ } \\
\text { cooked } \\
\text { sample }\end{array}$ & $\begin{array}{c}\text { Taste / } \\
\text { fried } \\
\text { sample }\end{array}$ & $\begin{array}{c}\text { Overall } \\
\text { Acceptability }\end{array}$ \\
\hline $\mathrm{T}_{1}$ & $5.1^{\mathrm{b}}$ & $6.2^{\mathrm{b}}$ & $5.4^{\mathrm{b}}$ & $5.5^{\mathrm{b}}$ & $5.5^{\mathrm{b}}$ & $5.7^{\mathrm{b}}$ & $5.5^{\mathrm{b}}$ & $6.3^{\mathrm{b}}$ \\
$\mathrm{T}_{2}$ & $5.7^{\mathrm{b}}$ & $5.7^{\mathrm{b}}$ & $5.7^{\mathrm{b}}$ & $5.8^{\mathrm{b}}$ & $5.7^{\mathrm{b}}$ & $5.8^{\mathrm{b}}$ & $5.8^{\mathrm{b}}$ & $5.5^{\mathrm{b}}$ \\
$\mathrm{T}_{3}$ & $2.8^{\mathrm{a}}$ & $3.2^{\mathrm{a}}$ & $3.9^{\mathrm{a}}$ & $4.4^{\mathrm{a}}$ & $4.8^{\mathrm{a}}$ & $4.2^{\mathrm{a}}$ & $4.5^{\mathrm{a}}$ & $3.8^{\mathrm{a}}$ \\
$\mathrm{T}_{4}$ & $3.1^{\mathrm{a}}$ & $3.3^{\mathrm{a}}$ & $3.8^{\mathrm{a}}$ & $4.5^{\mathrm{a}}$ & $4.8^{\mathrm{a}}$ & $4.7^{\mathrm{a}}$ & $4.9^{\mathrm{a}}$ & $3.7^{\mathrm{a}}$ \\
$\mathrm{T}_{5}$ & $6.4^{\mathrm{b}}$ & $6.3^{\mathrm{b}}$ & $6.1^{\mathrm{b}}$ & $5.4^{\mathrm{b}}$ & $5.8^{\mathrm{b}}$ & $5.6^{\mathrm{b}}$ & $5.7^{\mathrm{b}}$ & $6.3^{\mathrm{b}}$ \\
$\mathrm{T}_{6}$ & $5.0^{\mathrm{b}}$ & $4.5^{\mathrm{a}}$ & $3.6^{\mathrm{a}}$ & $5.2^{\mathrm{b}}$ & $5.0^{\mathrm{b}}$ & $4.8^{\mathrm{a}}$ & $5.0^{\mathrm{b}}$ & $4.4^{\mathrm{a}}$ \\
$\mathrm{T}_{7}$ & $3.3^{\mathrm{a}}$ & $2.8^{\mathrm{a}}$ & $3.0^{\mathrm{a}}$ & $4.2^{\mathrm{a}}$ & $4.8^{\mathrm{a}}$ & $4.4^{\mathrm{a}}$ & $4.7^{\mathrm{a}}$ & $3.0^{\mathrm{a}}$ \\
\hline
\end{tabular}

$\left(\mathrm{T}_{1}-3 \%(\mathrm{w} / \mathrm{v})\right.$ ascorbic acid, $\mathrm{T}_{2}-3 \%(\mathrm{w} / \mathrm{v})$ citric acid $\mathrm{T}_{3}-2 \%(\mathrm{w} / \mathrm{v})$ ascorbic acid, $\mathrm{T}_{4}-2 \%(\mathrm{w} / \mathrm{v})$ citric acid, $\mathrm{T}_{5}-1.5 \%(\mathrm{w} / \mathrm{v})$ citric acid $+1.5 \%(\mathrm{w} / \mathrm{v})$ ascorbic acid, $\mathrm{T}_{6}-2 \%(\mathrm{w} / \mathrm{v})$ sodium metabisulphite, $\mathrm{T}_{7}$ - distilled water (control)). 


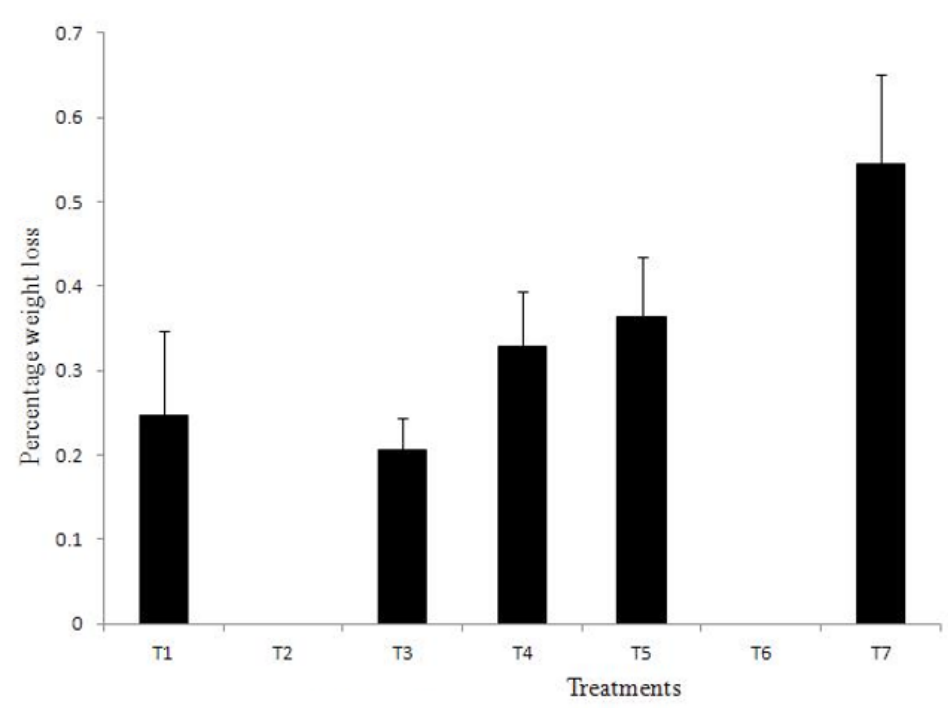

Figure 02. Effect of pretreatments on degree of browning of minimally processed cooking banana.

$(\mathrm{T} 1-3 \%(\mathrm{w} / \mathrm{v})$ ascorbic acid, T2 - 3\% (w/v) citric acid T3 - 2\%(w/v) ascorbic acid, T4 - 2\% (w/v) citric acid, T5 - $1.5 \%(\mathrm{w} / \mathrm{v})$ citric acid $+1.5 \%(\mathrm{w} / \mathrm{v})$ ascorbic acid, T6 $-2 \%(\mathrm{w} / \mathrm{v})$ sodium metabisulphite, T7 -distilled water (control)).

Data points of degree of browning (absorbance) represent the mean of three replicates \pm standard error.

Polyphenol oxidase inhibition by ascorbic acid has been attributed to the reduction of enzymatically formed $o$-quinones to their precursor diphenols. Ascorbic acid also acts as an oxygen scavenger, removing molecular oxygen in polyphenol oxidase reactions (Rico et al., 2007). Citric acid has been widely accepted as effective in reducing superficial $\mathrm{pH}$ of cut fruits such as orange, apple, peach, apricot, kiwifruit, avocado and bananas thus rendering polyphenol oxidase inactive (Soliva-Fortuny and Martin-Belloso, 2003). Cortez-Vega et al., (2008) evaluated the inhibitory effect of ascorbic acid and sodium metabisulfite on enzymatic browning of minimally processed apples. They reported that direct application of ascorbic acid and sodium metabisulfite on minimally processed apples packed in PVC films and stored at $5{ }^{\circ} \mathrm{C}$, conserved the original color of apples up to seven days. According to Ahvenainen, (1996) citric acid combined with ascorbic acid or alone showed promising results for pre-peeled potatoes. These observations are in accordance with our results indicating pretreatments used during our study have a positive impact in managing browning in minimally processed cooking banana.
The low temperature storage $\left(5-7{ }^{\circ} \mathrm{C}\right)$ used in this research was important in reducing adverse physical and chemical changes that would occur otherwise.

The packaging material used in the present study was polystyrene with clip on lids. No undesirable effects were observed due to this packaging material in the samples packed, i.e. off-odours or off-flavours. In addition, the packed material was easily visible through the package.

\section{CONCLUSIONS}

This study revealed a significant effect of pretreatments on physicochemical, sensory properties and degree of browning of cooking banana variety Alukesel. Present Research activity revealed the suitability of the pretreatments tested for a period of one week for maintaining freshness and quality at $5-7{ }^{\circ} \mathrm{C}$. Ascorbic acid and citric acid alone (at $3 \%$ ), and $1.5 \%$ citric acid $+1.5 \%$ ascorbic acid pretreated cooking banana were of better quality compared to other pretreatments tested. Since the packaging materials used was convenient and ideal for market display, these products could be sold as a value-added 
product at local supermarket chains where cold storage facility is available. Banana, processed using this technology could be used for cooking purposes and fried chips preparation.

\section{ACKNOWLEDGEMENTS}

Financial assistance provided by University of Kelaniya, Sri Lanka is highly appreciated.

\section{REFERENCES}

Abeywickrama, K., Kularathna, L., Sarananda, K. and Abeygunawardena, D. (2004). Cymbopogon citratus (lemongrass) and citral $\mathrm{a}+\mathrm{b}$ spray treatments alone or in combination with sodium bicarbonate in controlling crown rot in Embul banana (Musa acuminata AAB). Tropical Agricultural Research and Extention. 7: 04-111.

Ahvenainen, R. (1996). New approaches in improving the shelf life of minimally processed fruits and vegetables. Trends in Food Science and Technology. 7: 179-186.

Anthony, C.L.S. (2003). Essential oil treatments to control two post-harvest diseases of banana (Musa acuminata-cultivar Embul). M.Phil. Dissertation, Faculty of Graduate Studies, University of Kelaniya, Sri Lanka. 111pp.

Anthony, S., Abeywickrama, K. and Wijeratnam, W. S. (2003). The effect of spraying essential oils of Cymbopogon nardus, C. flexuosus and Ocimum basilicum on postharvest diseases and storage life of Embul banana. Journal of Horticultural Science and Biotechnology. 21: $211-216$.

Artes, F., Castaner, M. and Gil, M.I. (1998). Enzymatic browning in minimally processed fruit and vegetables. Food Science and Technology. 4(6): 377-389.

Botelho, M.C., Leme, S.C., Nunes, E.E., Boas, M.B.V., Boas, E.V. de B.V. and Chitarra, A.B. (2008). Quality of fresh-cut strawberry during storage. Acta Horticulturae. 768: 307-309.

Cortez-Vega, W.R., Becerra-Prado, A.M., Soares, J.M. and Fonseca, G.G. (2008). Effect of L-ascorbic acid and sodium metabisulfite in the inhibition of the enzymatic browning of minimally processed apples. International Journal of Agricultural Research. 3(3): 196201.

Dadzie, B. K. (1998). Post-harvest characteristics of black Sigatoka resistant banana, cooking banana and plantain hybrids. Inibap Technical Guidelines. International Plant Genetic Resources Institute. Rome. Italy. 34pp.

Daranagama, D. A. D. A. (2011). Pretreatments in managing microorganisms of minimally processed lotus root, pineapple and ambarella and controlling browning in lotus root under modified atmosphere packaging and cold storage. B.Sc. Dissertation, Department of Botany, Faculty of Science, University of Kelaniya, Sri Lanka. 42 pp.

Daranagama, A., Ediriweera S. and Abeywickrama K. (2012). Pretreatments and cold storage on the quality of minimally processed Ambarella (Spondias dulcis L.) and the mixed load of Ambarella and pineapple (Ananas comosus (L.) Merr). Journal of Science of University of Kelaniya 7: 21-41. 
Dharmabandu, P.T.S., De Silva, S.M., Wimalasena, S., Wijesinghe, W.A.J.P. and Sarananda, K.H. (2007). Effect of pre-treatments on extending the shelf life of minimally processed "Ela Batu" (Solanum surattense). Tropical Agricultural Research and Extension. 10: 6166.

Ekanayake, A. H. (2014). Pretreatments in managing microorganisms and browning in minimally processed Immature Jakfruit (Polos). B.Sc. Dissertation, Department of Botany, Faculty of Science, University of Kelaniya, Sri Lanka. 58 pp.

Latifah, M.N., Abdullah, H., Selamat, M.M., Habsah, M., Talib, Y., Rahman, K.M. and Jabir, H. (2000). Shelf life of minimally processed pineapple. Journal of Tropical Agriculture and Food Science. 28: 79-85.

Latifah, M.N., Aziz, I.A., Fauziah, O. and Talib, Y. (2008). Effect of packing methods on the quality of minimally processed green citrus cv. limau madu. Journal of Tropical Agriculture and \& Food Science. 36: 69-75.

Lozano-De-Gonzalez, P.G., Barrett, D.M., Wrolstad, R.E. and Durst, R.W. (1993). Enzymatic browning inhibited in fresh and dried apple rings by pineapple juice. Journal of Food Science, 58(2): 399-404.

Marshall, M.R. and Wei, J.C. (2000). Enzymatic browning in fruits, vegetables and seafoods. FAO. $52 \mathrm{pp}$.

Miller, D.D. (1998). Food chemistry, A Laboratory Manual. Wiley Interscience, New York, USA.

Mostofi, Y., Hajizadeh, H.S., Talaie, A. and Mousavi, M.A.E.Z. (2008). The effect of modified atmosphere packaging (MAP) on some physiochemical characteristics and texture of Iranian apple 'Shafi Abadi'. In: Proceedings of the XXVII IHC (Symposium 8), Seoul, Korea. 103-109.

Rico, D., Martin-Diana, A. B., Barat, J. M. and Barry-Ryan, C. (2007). Extending and measuring the quality of fresh-cut fruits and vegetables: a review. Trends in Food Science and Technology. 18: 373-386.

Schmidl, M.K. and Labuza, T.P. (2000). Essentials of functional foods. Aspen Publishers, Inc. USA. 108 pp.

Simmonds, N.W. (1966). Bananas. 2nd Edition. Tropical Agriculture Series, Longman, London. $512 \mathrm{pp}$.

Soliva-fortuny, R. C., and Martin-belloso, O. (2003). New advances in extending the shelf-life of fresh-cut fruits: A Review. Trends in Food Science and Technology. 14: 341-353.

Zaulia, O., Razali, M., Che Omar, D. and Habsah, M. (2007). Suitable sanitizing agent and pre-conditioning temperature to prolong shelf life of minimally processed onion (Allium cepa L.). In: Proceedings of the National Horticulture Conference, Malaysia. 271-275. 